\title{
COPEPODS IN AYIRAMTHENGU MANGROVE; KOLLAM
}

\author{
V.S. Ranjana*, S. Amina** \\ Research Department, S.D college, Alappuzha, Kerala*. \\ Post Graduate Department of Zoology, MSM College Kayamkulam.** \\ University of Kerala. \\ Email: ranjanavs1234@gmail.com
}

\begin{abstract}
Mangrove ecosystems are considered to be the most productive and complex wetlands. Ayiramthengu is situated about $6 \mathrm{~km}$ west of Oachira town on the bank of the Kayamkulam estuary, its an important part of this estuary. Present study is aimed to analyse the copepod diversity and water quality parameters in this region. Because copepods are one of the important group in zooplankton, they are important food for fishes and its relation with water quality parameters is very important. Copepods were collected monthly using plankton net $(60 \mu)$. During the whole study period (september 15 to august16) total 15 species of copepods are en counted belong in 3 order .6 species of cyclopoida,7 species calanoida and 2 species of Herpacticoida .Standard procedure are adopted for determination of physico-chemical parameters of water viz: , salinity, Temperature, $\mathrm{DO}, \mathrm{BOD}, \mathrm{pH}$, are found that influence the copepod diversity.
\end{abstract}

KEYWORDS: cyclopoida, calanoida, herpacticoida, mangrove ecosystem

\section{INTRODUCTION}

Copepods constitute one of the major zooplankton communities occurring in all types of water bodies. Among micro crustacean planktonic, the copepods Cyclopoida and Calanoida are one of the most representatives, being the largest biomass of the plankton community (Rocha and Matsumura- Tundisi ${ }^{15}$, 1984; González et al., 2008) $)^{15,8}$. Thy are ubiquitos and small like the terrestrial ants. ${ }^{11}$

Copepods are much hardier and strongly motile than all other micro invertebrates with their tougher exoskeleton and longer and stronger appendages. They have long developmental time and a complex life history with early larval stages difficult to distinguish. ${ }^{8}$ copepods are main grazers of phytoplankton. The oral appendages are flattened, multi lobed structures carrying long plumose setae. They are feed voraciously taking in much more than they can digest and absorb. Much of they eat passed out undigested. There is however no waste of food since the excreta is consumed by other animals or broken down by bacteria and the nutrients contained in it recycled ${ }^{11}$. So they play an important role in aquatic ecosystem.

Mangrove are specialized ecosystem developed along estuarine sea coasts and river mouths in tropical and subtropical regions of the world. The salt marshes and mangrove forests act like enormous filters. As water flow through this regions filter pollutants such as pesticides and heavy metals out of water as well as excess sediments and nutrients (USEPA, 1993). Present study was undertaken in the mangrove habitats of Ayiramthengu, a 
portion of kayamkulam backwater. The mangrove ecosystem and its biological components are under the influence of both freshwater and marine condition and have developed a set of physiological adaptation to overcome problems of anoxia, salinity and frequent tidal inundations. This has led to the assemblage of a wide variety of plant and animals species of special adaptations suited to the ecosystem. copepods assume a great ecological significance in mangrove ecosystem as this ecosystem is the feeding, breeding and nursery ground of many fin and shell fishes.

The copepod diversity of surface waters of various water bodies have been studied by a number of investigators ${ }^{6,8}$. Studies made on copepods of Ayiramthengu mangrove is limited. A very few literature has been found on the plankton community of Ayiramthengu mangrove which is a part of kayamkulam back water such as ${ }^{12}$ and Amina.et.al ${ }^{3}$. Thus the present study was done to find out the diversity of copepods in this region.

\section{STUDY AREA}

Ayiramthengu mangrove $\left(9^{0} 6\right.$ to $9^{0} 8$ $\mathrm{N}: 76.28^{\circ}$ to $76.29^{\circ} \mathrm{E}$ ) is situated about 6 $\mathrm{km}$ west of Ochira town and the bank of kayamkulam estuary. Which is a narrow stretch of tropical backwater on the west coast of peninsular India. The mangrove here covers 20 acre of area. This long chain of mangrove vegetation is the only extensive one left almost touched by man along Kerala coast. The area is mounted on east by kayamkulam estuary on the west by the kollam- Alappuzha water ways connected to Arabian sea on north and south by two canal. The flood water of Pampa and Achankovil rivers flow into the estuary. Ayiramthengu mangrove forest was declared an environmental hot sport after it was ravaged by the Tsunami 2004 and threatened with extinction.

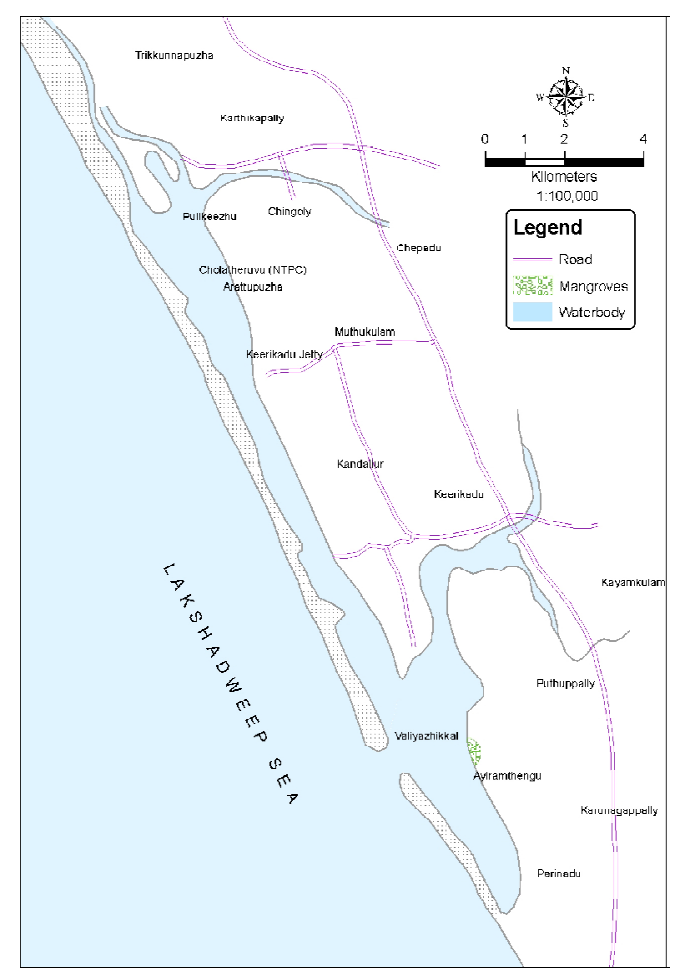

\section{STATION INVESTIGATED}

The stations selected were having different ecological status

1. Station $I$ is characterised by influx of fresh water into mangrove 
2. Station II represent the luxuriant mangrove growth showing entangled the respiratory roots

3. Station III represent open area air tight and waves are predominates

\section{MATERIALS AND METHODS}

\section{(a) Hydrology:}

To study the hydrological parameters water samples were collected monthly from three stations and brought to the laboratory and analysed. Water temperature, $\mathrm{pH}$, dissolved oxygen, carbon dioxide, salinity, hardness, TDS, BOD were carried out by standard procedure (APHA,2005).

\section{(b) Collection of zooplankton}

The plankton samples collected by filtering 50 liter of water through standard planktonic net $(60 \mu)$ and concentrated sample were preserved in 5\%formalin in $100 \mathrm{ml}$ vial and identified with the help of standard keys.

\section{RESULTS AND DISCUSSION}

The mean value of various hydrological conditions recorded during the whole study period are given in table 1 .and figure 1. Water temperature, $\mathrm{pH}$, and Dissolved oxygen are highest in station3, maximum value of free carbondioxide and biological oxygen demand are seen in station 2 and highest value of salinity was shows in station 3 .

Table: 1 Hydrological conditions of surface water at Ayiramthengu mangrove (mean value)

\begin{tabular}{|l|c|c|c|}
\hline \multirow{2}{*}{ Parameters } & \multicolumn{3}{|c|}{ Sampling stations } \\
\cline { 2 - 4 } & Station I & Station II & Station III \\
\hline water Temperature $\left({ }^{0} \mathrm{c}\right)$ & 27.92 & 27.72 & 27.98 \\
\hline $\mathrm{p}^{\mathrm{H}}$ & 7.09 & 7.14 & 7.29 \\
\hline Dissolved oxygen $(\mathrm{mg} / \mathrm{l})$ & 4.54 & 4.34 & 4.69 \\
\hline Free carbondioxide $(\mathrm{mg} / \mathrm{l})$ & 5.68 & 6.07 & 5.46 \\
\hline Salinity & 31.83 & 32.07 & 32.48 \\
\hline Biological oxygen demand & 2.26 & & \\
\hline
\end{tabular}




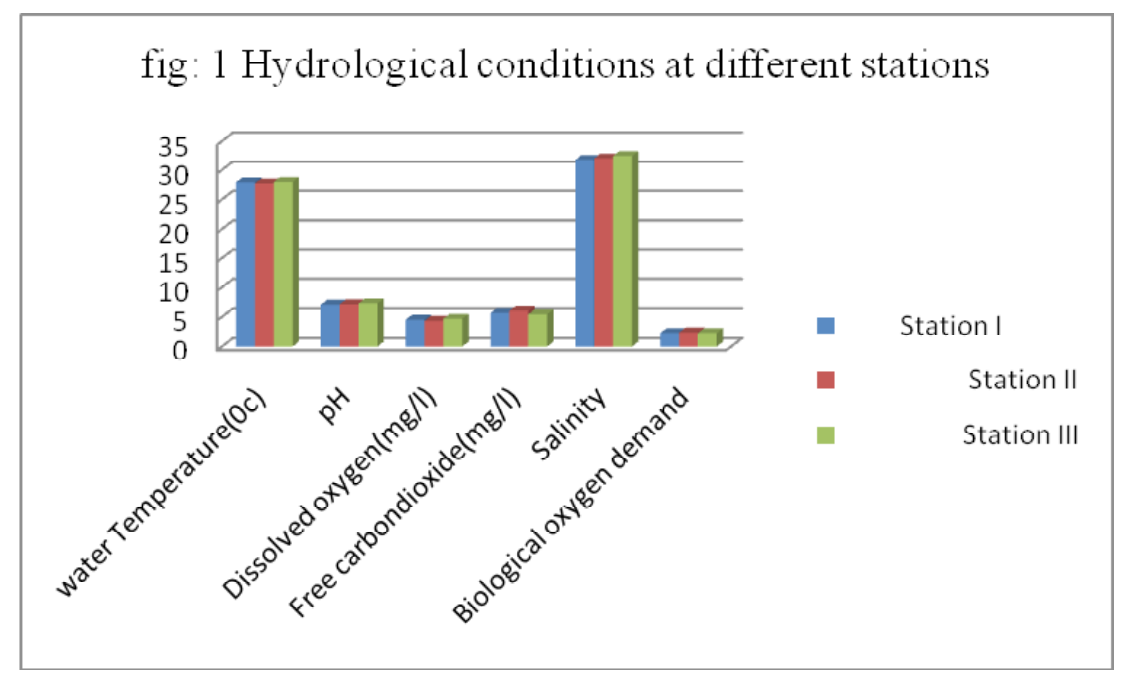

Table 2 List of copepods species recorded in Ayiramthengu mangrove (Sept 2015 to Aug 2016)

\begin{tabular}{|l|l|c|c|c|}
\hline Order & copepod species & Station I & Station II & Station III \\
\hline cyclopoida & Mesocyclops leuckarti (Claus) & $*$ & $*$ & $*$ \\
\hline & M. hyalines & $*$ & $*$ & $*$ \\
\hline & M. aspericornis & $*$ & $*$ & $*$ \\
\hline & Thermocyclops sps & $*$ & & $*$ \\
\hline & T.crcessus & $*$ & $*$ & $*$ \\
\hline & Eucyclops agilis & $*$ & $*$ & $*$ \\
\hline & Acarita centura (Giesbrecht 1882) & & $*$ & $*$ \\
\hline & A.majar & $*$ & $*$ & $*$ \\
\hline & Diaptomes sps (Baird,1850) & $*$ & $*$ & $*$ \\
\hline & Paracalanus parvus (Calus) & $*$ & $*$ & $*$ \\
\hline & Acrocalanus longicornis (Giesbrecht) & $*$ & $*$ & $*$ \\
\hline & A.gibber (Giesbrecht) & $*$ & $*$ & $*$ \\
\hline & Ponetella danae (Giesbrecht) & & $*$ & $*$ \\
\hline
\end{tabular}

28 • J. Adv. Zool. $2019: 40(1)$ 


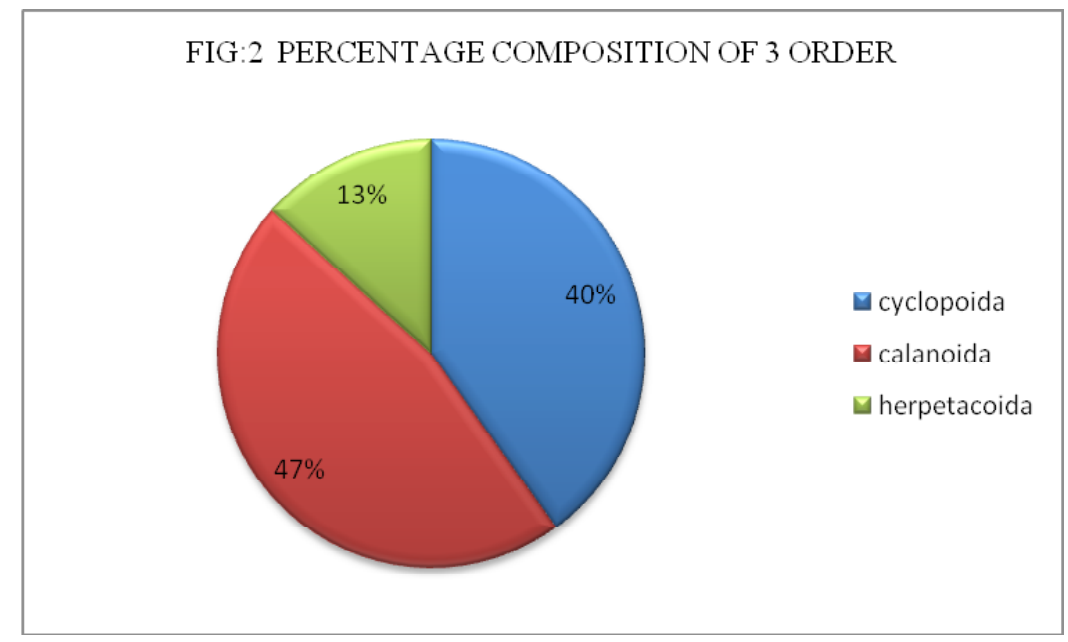

List of copepods recorded in study area composition of three order also prove is list in table 2 and the percentage this.(figure 2). They are probably the most ecologically significant animals at the first composition of three order are shows in figure 2. Which shows that during the study consumer level of the marine plankton and period 15 species of copepods belonging 3 order were noticed .6 species cyclopoida, 7 species calanoida and 2 species belong to harpacticoida. List of copepods species recorded in Ayiramthengu mangrove (Sept 2015 to Aug 2016) shows above. Order calanoida is the most dominate group in Indian water (A.Biju.2017). The percentage are also the most prominent among the primary carnivores. Present study shows that the order calanoidae standing the dominant than the cyclopoida and herpacticoida. and according to Shannon diversity index station 3 has highest diversity than other two stations.

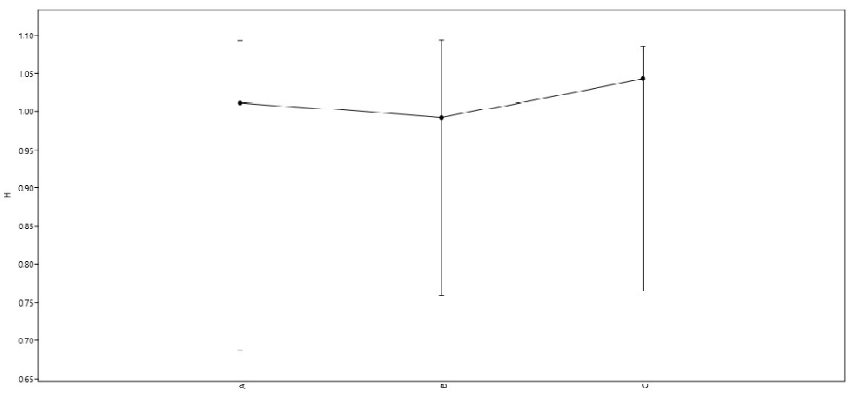
A: $\quad$ station3
B: station 2
C: station 1

Fig : 3 Shannon diversity status at three stations. 
Copepods have been regarded as being good indicator of climatic trends and anomalies although they are generally considered as part of zooplankton community. They are common in the coastal and estuarine waters, indicating nearness and linkage to the mangrove environments. copepods are excellent candidate for the study of ecosystem response to climate variability because their life cycle is short. This characteristic makes copepod populations potentially capable to respond to environmental changes and reflect eventscale changes in environmental conditions, hence provide early indications of biological response to climate variability. Moreover, many copepod species are known to be indicator species, whose presence or absence may represent the relative influence of different water types on ecosystem structures. The results found during the present study shows presences of different species of copepods.

The copepod diversity is closely related to water quality parameters and it also related the fish fauna of the water body.

\section{REFERENCES}

1. Altaff, K., 2004. A manual of zooplankton. University Grants Commission, New Delhi, pp. $1-145$

2. Biju, A., 2017. A hand book on marine zooplankton, Research department of zoology, St. Stephen's College publishing, Kerala.

3. Amina, S., 2012. Seasonal distribution of chlorophyceae in kayamkulam back water, Intern. J. Iinsti. Pharmacy and Life Sci., 716.
4. APHA, 2005. Standard methods for the examination of water and waste water. $21 \mathrm{st}$ Edn., APHA, AWWA, WPCF, Washington, D.C., USA.

5. Battish, S.K., 1992. Freshwater zooplankton of India. Oxford and IBK Publishing Co. New Delhi.

6. Dussar, T.B.H. and Defaye, D., 1995. Copepoda: Introduction to Copepoda, SPM Academic Publishing bv: 6- 7 .

7. Godhantaramam N., 1994. Species composition and abundance of tintinnids and copepods in the Pichavaram mangroves (South India), Ciencias Marinas, 20 371- 391.

8. González, et.al., 2008. Size and dry weight of main zooplankton species in Bariri reservoir (SP, Brazil). Brazilian Journal of Biology, vol. 68, pp. 69-75.

9. Gunwati V. Arak., 2012, Copepod Diversity of Tembhapury Lake Aurangabad Region, M.S, India. International Journal of Science and Research (IJSR).

10. Kathiresan, K. and S.Z. Qasim, 2005. Biodiversity in mangrove ecosystem, Hindustan Publishers, New Delhi.

11. Krishna pillai, N., 1986. Introduction to planktonology, Himalaya publishing house, Mumbai.

12. Mary John, 1958. A Preliminary study on Kayamkulam lake. Bull. central Res. Inst. University of Kerala. Trivandrum, 7(1);97116.

13. George J. Parayannilam and Naomi.T.S., 2005. Mangrove Ecosystems-A manual for the assessment of biodiversity, CMFRI special publication No 83. Cochin, 36-82.

14. Sudararaj, V. and K. Krishnmurthy, 1975. Nutrient and Plankton; Backwater and Mangrove Environment. In:Recent Researches in Esturine biology, R (Ed), Hindustan Publishing Corp., New Delhi, 273290.

15. Qasim, S.Z., 2005. Zooplankton of some major estuaries of India J. Indian ocean stud..439446. 
16. Rocha, O. and T. Matsumura-Tundisi, 1984.

Biomass and production of Argyrodiaptomus furcatus a tropical calanoid copepod in Broa reservoir, southern Brazil. Hydrobiologia, vol. 113, pp. 307-311. 